\title{
Worker Movement as a Union Issue: An Examination of Collective Bar- Gaining Agreements In THE CONSTRUC- tion Sector in Alberta, Canada
}

\author{
SusAn CAKE
}

\begin{abstract}
The fluctuating expansion of oil sands development in northern Alberta, Canada has led to employers hiring a large number of mobile workers. The working conditions for some of these mobile workers are modulated in part by unions through their role in negotiating collective bargaining agreements. Using a social reproductive framework, this study has two main findings: through collective agreements mobile workers are treated as a distinct category of worker, and there is a simultaneous expansion of workplace rules and regulations alongside a divide of the workplace from the home. The resulting expansion of the union regulated space in contrast to the divide of workplace from the home challenges union revitalization efforts, while also reaffirming traditional gendered experiences of mobility.
\end{abstract}

Keywords: Long-distance commuters, mobility, collective bargaining agreements, union renewal, Canadian Labour movement

Résumé. En raison de l'expansion variable du développement des sables bitumineux au Nord de l'Alberta (Canada), les employeurs se sont vus contraints d'engager un grand nombre de travailleurs nomades. Les conditions de travail de certains de ces travailleurs nomades sont modulées en partie par les syndicats, en raison de leur rôle lié à la négociation des conventions collectives. À l'aide d'un cadre de travail fondé sur le concept de reproduction sociale, cette étude a permis de tirer deux principales conclusions : i) par le biais de conventions collectives, les travailleurs nomades sont traités comme une catégorie distincte de travailleurs ; ii) parallèlement, il y a une expansion des règlements relatifs au milieu de travail couplé d'un clivage entre le milieu de travail et le domicile. L'expansion résultant de l'espace réglementé par les syndicats, par opposition au clivage entre le milieu de travail et le domicile, compromet les efforts de revitalisation des syndicats, tout en réaffirmant les expériences sexospécifiques traditionnelles de mobilité. 
Mots clés: Navetteurs à grande distance, mobilité, conventions collectives, renouveau syndical, mouvement syndical canadien

\section{INTRODUCTION}

pproximately 34 per cent of people living in the Regional Municipality of Wood Buffalo (RMWB) in Alberta, Canada are considered part of a geographically mobile population of workers (RMWB 2013). ${ }^{1}$ With easier access to efficient travel, we are seeing an increase in different types of geographically mobile workers (Newhook et al. 2011: 125-126) who have received relatively limited attention in the social sciences" "mobility turn" (Sheller and Urry 2006). Particularly underresearched is how collective bargaining agreements between employers, provincial trade divisions and trade unions structure workers' geographic mobility. The topic of mobility is especially interesting given union revitalization efforts in many Western countries (see Phellen 2007; Frege and Kelly 2004) and those specifically focusing on Canada (see Hunt and Rayside 2000; Kumar and Schenk 2006; Camfield 2011). This study on worker mobility and unions specifically draws from Briskin's (2011) and Yate's (2004) claims that for unions to renew they must expand what issues they deal with, for example including issues such as child- and healthcare. ${ }^{2}$ These revitalization efforts aim to expand issues unions can officially respond to in their collective bargaining agreements, helping unions stay relevant to workers.

Drawing on 50 collective bargaining agreements spanning from 2007 to 2019, I explore how unions and employers respond to the large population of mobile workers in the RMWB and how this response affects what is considered a union issue in collective agreements. I begin with a brief outline of literature on worker mobility in Canada and then follow with a description of the social reproduction framework that helps us understand the role of these collective agreements with regards to mobility and union issues. In the analysis section I provide an overview of

1. According to the 2012 RMWB census, the results should be used with caution since the census was conducted at a time with historically low numbers of people in temporary housing. The total number of approved temporary housing beds in 2012 was 82,825 . This count does not include people who stay in private residences while maintaining a permanent residence outside of RMWB. Considering these cautions, 34 per cent is a conservative estimate.

2. See Briskin, 2006, 2011 for examples of how changing worker demographics, as a source of renewal, can lead to changes in issues that unions address; see Smith, 2014 for an example of a Canadian union broadening their bargaining agenda. 
the results and a discussion of three general findings: that local residents are defined and treated as a distinct category of workers; that including worker transportation and living arrangements in these agreements expands what can be considered a workspace and a union issue; and that the expansion of these agreements into other spaces also allows a divide between workspace/market space and private homes as well as the masculine and feminine in terms of mobility and union issues.

\section{Context}

The flows of worker migration to and within Canada has varied, largely responding to the needs of capital. Although not the focus of this paper, other researchers have taken up worker mobility from studies of commutes to labour migration. Research on commuting highlights different inequalities between workers including commuting times, lengths and efficiencies that further depend on where workers live and work, the local infrastructure facilitating commuting and even demographics of the commuters (Edensor 2011; Partridge and Nolan 2005; Green 2004; Hanson 2010). In contrast to research on commutes are those focusing on permanent and circular international labour migration to Canada (for example Barber 2008; Schiller and Salazar 2013; Salazar 2011; Flecker 2010; Fudge 2012). As well, researchers have examined different Canadian programs to facilitate circular international labour movement including the Temporary Foreign Worker Program (Barnetson and Foster 2014; Fudge and MacPhail 2009), the Live-In Care Giver Program (Bakan and Stasiulis 1997) and the Seasonal Agricultural Worker Program (Hennebry and Preibisch 2012; Preibisch and Binford 2007). The migration literature on interprovincial migration in Canada has focused on the permanent movement of workers from one location to another, showing a tendency for these flows to go in one direction (Newhook et al. 2011). In the early 1980s workers relocated from southwestern Ontario to Alberta; however, this flow reversed itself in 1982 as industrial workers returned to Ontario (High 2003). This period was followed by waves of workers travelling to Alberta from Ontario, Quebec and the east coast of Canada, (Statistics Canada 2015) as well as many temporary international workers (Barnetson and Foster 2014) despite the economic downturn of the oil sands.

To help promote interprovincial worker mobility the Canadian government developed clauses in both the Canadian Charter of Rights and Freedoms (1982) and the Canadian Agreement on Internal Trade (1995) promoting employment-related mobility. Under the Charter the govern- 
ment established the subject position of citizen in relation to mobility in section 6 , which specifically protects employment-related mobility rights of Canadian citizens stating:

6. (2) Every citizen of Canada and every person who has the status of a permanent resident of Canada has the right

a) to move to and take up residence in any province; and

b) to pursue the gaining of a livelihood in any province.

Chapter 7 of the Agreement on Internal Trade aims to eliminate barriers to the movement within Canada not only of citizens but also goods, services and investments. Although this agreement does exist there are still reported barriers to worker mobility in Canada as evidenced by the several provincial agreements (for example, the Trade, Investment and Labour Mobility Agreement between Alberta and British Columbia (2006) and the New West Partnership Trade Agreement (2010) that includes Alberta, British Columbia and Saskatchewan). These provincial level trade agreements aim to harmonize trade recognitions so workers can move freely between the provinces. Despite these agreements there are still some barriers in place, such as limited recognition of training experience for those still in training (Mertins-Kirkwood 2014; A Workforce Strategy for Alberta's Construction Industry 2007).

Since Canada has a lengthy history of worker mobility because of an economic dependency on "staples" and natural resources requiring mobile workforces (Newhook et al. 2011: 122), there is a strong history of long distance travel for work and of company towns and camps made to house workers. Often these "company towns" were set up to attract a stable labour force to an isolated area (Borges \& Torres 2012: 1; for more information see Lucas 2008). When booming, natural-resource economies located in remote regions still attract many people to permanently relocate to places like Alberta (Barnetson and Foster 2014); however, with new access to and efficiencies of long-distance travel there are more opportunities for workers to become long-distance commuters within Canada through fly-in fly-out arrangements - flying into their work location for a set period of time and then flying to their "homes" for another set period. Using the spectrum of employment-related geographical mobility (E-RGM) (Green 2004; Newhook et al. 2011) - a spectrum that highlights various forms of mobility from short daily commutes to more long-distance travels across national or international boarders - fly-in fly-out is positioned between international circular migration and daily 
commuting and commonly referred to as long-distance labour commuting, or simply long-distance commuting (Bell and Ward 2000). With more workers taking part in these long distance commutes Canadian and Australian companies are investing in what Storey (2010: 1161) terms the "no town" model. This model encourages work-camp facilities traditionally justified by assuming the workers living in camps use fewer services and infrastructure than workers staying in towns (Storey 2010: 1166). This line of reasoning also justifies the use of long-distance commuters (Barnetson and Foster 2014; Foster and Taylor 2013) as long as they can be housed and transported away from the established community and sent home when they are no longer needed.

Within the mobilities body of literature, very few studies of E-RGM examine collective agreements covering workers and the role of these union- and employer-negotiated contracts in workers' lives. Trades unions have been dealing with worker mobility and the geographical span of Canada for years. Many workers in Canada, "faced similar threats and trends, but geographical separation prevented them from recognizing the fact" (Palmer 1992: 50). As well, labour law in Canada is provincially regulated further dividing workers and resulting in some inconsistencies and unevenness. Labour law links local unions to specific workplaces, a practice that did not work well with construction projects where worker mobility is often the norm (Tucker and Jowett 2014: 3). Discontent with the collective bargaining structure in the 1960s led to drastic changes for the construction industry resulting in more centralized bargaining that covers geographical locations instead of specific worksites (Rose 2012). By basing agreements on geographic locations instead of worksites unions and employers could more easily deal with both the cyclical nature of the construction industry in terms of jobs but also worker mobility. However, the division between provinces and territories and various crafts still impacts the collective agreements under which workers fall.

This analysis includes trade unions of which most are national or even international unions with locals across the country. In the case of trade unions in Alberta, even if they are part of a larger national or international union, their collective agreement is only for the local representing people working in Alberta. The links between local unions under the same parent union tend to be weak at best (Camfield 2011). However, because of the provincial labour laws workers in this sector are still divided along traditional craft lines of work. These divides can mean that different collective agreements cover different workers at the same jobsite. For the collective agreements used in this analysis, the most common geographical jurisdiction is the entire province of Alberta (48/50), 
with some including areas in the Northwest Territories (32/50). For the purposes of this paper, the most important aspect of union jurisdictions is that the collective bargaining agreements are tied to the specific geographical space where the labour takes place, which may or may not include the location where the employee lives.

\section{THEORY}

The Canadian policies related to mobility echo a conception of a rationally mobile person. During the 1960s and 1970s, classic migration theory invented the idea of a "rational-mobile-person" who made decisions logically about when and where to move (Cresswell and Merriman 2011: 2). This person was expected to carefully weigh the advantages and disadvantages of relocating and ultimately decide on what was in their best interest, as a rational choice. This kind of mobile figure denies how social factors such as gender, class, ethnicity, wealth, age, sexuality and nationality influence people's ability to be mobile (Cresswell and Merriman 2011:9) while promoting an economic rationality. Documents such as the Charter and the Agreement on Internal Trade perpetuate the idea of the rational-mobile person. Newspaper and sectorial accounts highlight workers travelling to RMWB as selecting the best financial option for their family (Freeman 2015; Construction Sector Council 2005). As well, previous studies have highlighted the typical mobile worker traveling to Alberta is a married, middle-aged man (30-49 years old) with an average of two dependents under the age of 18 (Construction Sector Council 2005). With the acceptance of a new kind of mobile worker, we see a new rational long-distance mobile person whose decisions are driven by finances divorced from other considerations.

Building from Kate Bezanson and Meg Luxton (2006) along with Roseman, Barber and Neis (2015), I use the concept of social reproduction to understand the role of collective agreements not only in governing work arrangements but also outlining what is a "union issue" or a "workplace issue" and, by extension, what is a "private" or "home issue." Bezanson and Luxton (2006: 3) outline their theory of social reproduction:

Embedded in a feminist political economy framework, social reproduction offers a basis for understanding how institutions interact and balance power so that the work involved in the daily and generational production and maintenance of people is completed. 
These balances of power reflect differences of gender, class and race/ ethnicity (Bezanson and Luxton 2006: 4). Neoliberal policies and practices in Canada have shifted responsibility from the federal government to the provinces and, as logically follows, to families and individuals (Bezanson and Luxton 2006: 4).

This shift, according to Bezanson and Luxton (2006: 5), ideally showcases the "state-market-family/household-third sector nexus." When responsibilities shift to families and individuals, these responsibilities commonly fall to women. As social reproduction responsibilities fall to women in households we start to see how mobility and certain forms of work (paid and unpaid) end up divided along gendered lines. The framework of social reproduction helps focus attention on how the relations between paid and unpaid work in addition to those between home and workplace are integral to the economy; this focus provides a lens for understanding the role of collective bargaining agreements in these gendered relations.

Leah Vosko's (2006) concept of precarious employment adds another layer to the social reproduction framework. Precarious employment is characterized by uncertainty, a lack of worker control, low income and limited access to regulation or protections. Precarious employment is influenced by several factors, including the form of employment (full-time compared to non-standard forms of employment including part-time and seasonal), employment status (self-employed, paid employment, contractor) and social context and location. Considering the different levels of employment precarity, the least precarious situation is the standard-employment relation (SER) (Vosko and Clarke 2009: 27), which is defined as full-time, continuous work normally happening on the property of a single employer. More precarious forms of employment include non-standard forms of employment such as part-time and seasonal work, as well as dangerous work that comes with limited benefits and low wages, where workers have limited control over their tasks/ responsibilities.

The SER has shaped social reproduction in Canadian households (Vosko and Clarke 2009: 27). Many of the social and economic structures of employment attempting to balance social reproduction assume a male breadwinner with a SER who distributes his earnings and benefits to the family. Therefore, as Vosko and Clarke (2009: 27) argue, the SER shapes familial obligations and the organization of households and 
labour force participation that may be reflected in collective bargaining agreements. ${ }^{3}$

By understanding the concept of the rationally mobile person and using a social reproduction framework combined with the concept of SER we can begin to see how unions become involved in the state-market-family nexus through collective agreements in relation to worker mobility. Long-distance commuters and local workers are treated differently, as indicated by which parts of their employment are considered union issues and included in collective bargaining agreements and which parts are left out.

\section{Мethod}

The agreements I used in this project are those found on the Construction Labour Relations - Alberta website (an employer association representing construction companies for the purposes of collective bargaining, labour law and other joint initiatives (Accessed: January 19 2015), cross referenced with the Building Trades of Alberta website (an umbrella organization of 16 Alberta trade unions (accessed: January 19 2015)). If websites were linked on the Construction Labour Relations website I also followed up to see if agreements were readily available. The aim with this sampling was to collect the most recent set of collective agreements available. A cut off year of 2011 was set when multiple agreements were available and if only one agreement was available for a sector it was used regardless of date. ${ }^{4}$ In addition to the collective agreements, one other agreement is included in this analysis: The Construction Camp Rules and Regulations (2010-2018) agreement signed by the Building Trades of Alberta and the Construction Labour Relations - An Alberta Association. This additional agreement has the same format as

3. The workers covered under these collective agreements are by no means the most precarious mobile workers or the most precarious workers in the area of RMWB. Because of collective bargaining agreements, these employees have protections that non-unionized workers do not. Yet, not all workers covered under these agreements are treated the same, and in a way, these agreements further institutionalize certain groups of workers as more or less precarious compared to others. It is also noteworthy, that being covered by a collective agreement does not mean there is equal protection from precarity. Rather, analyzing collective agreements reveals varying degrees of precarity according to different classifications under the agreement.

4. In total, three agreements started before 2011, and the remaining agreements were from 2011 and onwards. Of the agreements, 19 are from 2015 and therefore provide material negotiated during the recent downturn in the price of oil. 
the other collective bargaining agreements in this analysis, the same or similar signatories and connects the camp space and rules through penalties affecting a worker's employment. The total sample includes 50 collective agreements from 15 different trade unions and the agreement covering the work camps. While a number of these agreements include both industrial and commercial work, this analysis focuses on the industrial work portions of the agreements. I selected these agreements and organizations as they broadly cover the unionized construction sector across Alberta. Although examining agreements in one province and sector limits the generalizability of any findings, it also ensures any variation in the findings are not the result of different social, political, economic or legal contexts.

Using qualitative content analysis to examine these collective bargaining agreements for clauses related to mobility or mobile workers, I discovered several consistent trends and clauses across the agreements defining union issues and outlining working conditions. Although there were specific sections dealing with the location of workers, I examined the entire contract to ensure that isolated clauses were also included. Building from the qualitative content analysis of Denzin and Lincoln (1994) as well as other researchers who use this method to examine collective agreements (Cohen-Vogel 2013; Kiss and Mosco 2006; Julius and Gumport 2003), I coded each agreement considering the topics of mobility and social reproduction (e.g., transportation, accommodation, travel allowances). I created a series of codes and frames through an iterative process to ensure the capture of all clauses relevant to worker mobility and social reproductive work. Since this is one of the first research projects to examine collective agreement clauses for mentions of mobility or mobile workers, I relied on existing research on worker mobility in Canada as a sensitizing tool for coding.

\section{Results}

The results section covers findings related to how unions and employer associations negotiate worker mobility into the collective bargaining agreements. In general, the first set of findings presented here focus on how local workers are defined and categorized and thereby given preference for employment opportunities and union membership. I examine how this preference is often stated outright and then echoed in hiring and lay-off procedures, which are presented next. I then shift the results to focus on how different spaces, such as camp accommodations, have entered collective agreements. Lastly, I provide a brief overview dem- 
onstrating how transportation and rotational leave are laid out in these agreements.

\section{Location-Specific Preferences for Hiring and Lay-Off Decisions}

The majority of collective agreements (42/50) in this study use some variation of this statement: "the early participation of local resident Employees in work undertaken under this Agreement is most desirable and will be strongly promoted" (Carpenters 2011: 11.04 g) or "Notwithstanding anything in this Agreement, local residents who are union members shall have preference for employment" (Refractory Bricklayers 2015: 9.01) to ensure local workers have preference for employment. For both the Labourers - General Construction collective agreements used in this analysis, preference for local residents is only given when a client makes an explicit request for local workers.

Setting out categories of workers - in this case local and non-local - raises questions around the opportunities for long-distance commuters, how workers are defined and who is responsible for categorizing workers. Most of the collective agreements giving preference to local residents have a section defining what a local resident is (40/50) and even terms for defining "real residency." The first general criteria to be a local resident involves distance and time. Residing for at least the past six months within a 75-kilometre radius of the jobsite or the cities of Calgary and Edmonton is a common requirement (38/50). Unfortunately for long-distance commuters, to be considered a local resident requires some form of time commitment to a residence that may not be possible for highly mobile people - especially those who work jobs requiring them to travel for extended periods and therefore may not keep a permanent residence.

After a person is determined to be a local worker or not they are then hired according to the priority outlined in the collective agreement. The union must send qualified workers to a jobsite within 48 hours; otherwise the employer is free to bring workers on from other sources $(35 / 50)$. For example, the Bricklayers Union gives first preference to union members belonging to their locals, then members of other union locals in Alberta and from there members of the Bricklayers Union across Canada. The collective bargaining agreement for Insulators gives preferential hiring to local union members first, then local non-union members and finally other union members regardless of their geographical residence aside from any name-hiring rights an employer may use. ${ }^{5}$ A number $(27 / 50)$ of collective agreements specifying that the "Parties recognize that it is in

5. Name hiring is when an employer names the workers they would like hired. 
their mutual best interest to include significant involvement of women, aboriginal people, visible minorities and RAP [Registered Apprenticeship Program] students in the workforce" (Carpenters 2011: 4.08). There is very limited detail on how the union or the employer associations ensure participation from these populations beyond encouraging them to become apprentices. These practices ensure a local preference as well as a preference for union workers. In most collective agreements, longdistance commuters are the last to be hired after the local labour is exhausted.

Aside from hiring-preference, most collective bargaining agreements include a process for layoffs that once again depends on categories and positions long-distance commuters as vulnerable in comparison. Generally, the first people laid off are probationary union members and those from outside of Alberta, otherwise known as travel card members or permit holders (27/50). Categorizing these members as "non-local" semantically denotes them as temporary or in transit through the travel cards, making their employment more precarious compared to local residents. This kind of ordering in lay-offs further reinforces that these travelling and long-distance commuters have particularly uncertain labour situations -the workers are hired only when available work exceeds the local working population and are then dismissed when the labour demand drops.

\section{Camp Accommodations}

Workers assigned to remote sites far from their homes usually have the option to stay in work camps. These camps have physically evolved from a few mobile trailer homes to sprawling complexes containing dining halls, leisure spaces and dormitory-style accommodations (Ferguson 2011). These camp spaces also have their own rules and regulations through The Construction Camp Rules and Regulations (2010-2018) agreement. This agreement outlines behaviours (e.g., violence, bullying), substances (e.g., illegal drugs) and items (e.g., firearms, ammunition) prohibited on camp property, in addition to the rules governing the social reproduction of the labour force while workers are living in the camps (e.g., food allocations). Aside from the separate rules governing camps these places also have separate grievance procedures provided in the camp rules that mimic union collective agreements. Provided reasonable grounds, camp accommodations management may search workers' rooms in the presence of the worker and the camp steward. If a worker does not consent to this search, they can be removed from camp and/or locked out of their room until a peace officer searches the room. Liv- 
ing under rules requiring you to submit to a search or potentially lose your accommodations changes the space where employees sleep during off-hours from a private space to a kind of extension of the workplace. Furthermore, employees who are required to move to another camp room are paid for moving their belongings and this time counts towards working hours; tasks in this space count as paid labour. Workers included under the Industrial Carpenter and Cement Masons agreements forfeit the room and board allowance if they are absent from work before or after a weekend or holiday, a rule collapsing their living space in camps with their employment. All of these factors imbricate the living space of workers in the oil sands with their work.

\section{Transportation and Rotational Leave Clauses}

The collective agreements also govern transportation. In the case of the long-distance commuters, the use of company or commercial vehicles changes the commute from a somewhat private space to an extension of the workspace. Several of the collective bargaining agreements (29/50) even call for, but do not outline, a set of rules to govern behaviour during transportation $^{6}$, further demonstrating how these spaces are surveilled and controlled differently than private transportation. Also, any workers taking commercial transportation are governed by the rules of transportation companies in addition to any employer's rules. ${ }^{7}$ Workers must also meet qualifications in order to be compensated for travelling long distances. Although many workers covered under these collective agreements have a travel allowance upfront to pay for transportation costs to a site, many must work a certain period of time to keep the initial travel allowance and further qualify for a return transportation allowance. Thus, if remote workers are unable to fund their own travel costs, they are forced to work until they finish the qualifying period or have saved up the required funds. These circumstances remove the agency for workers to decide when they no longer want to work or how they commute.

Eligibility for rotational leave or turnaround allowance to spend time at home also has a qualifying period. In most collective agreements a geographical requirement stipulates workers live at least 300 kilometre from the centre of Edmonton or Calgary to qualify for a rotational leave

6. The collective agreements in this study only call for these rules but do not outline them. Upon further investigation I was not able to find examples of these rules.

7. The rules for private companies vary for each company and the kind of transportation they provide. An example of rules private transportation companies would be items passengers are not allowed to take on as carry-on items for example heavy tools or liquids over a certain amount. 
$(35 / 50)$. Employees under these agreements receive a rotational allowance after a certain number of days on the job, similar to the transportation allowance. Some workers are given a trip allowance when they take their rotational leave and a reimbursement for the return fare only once they return.

\section{Discussion ANd Analysis}

According to Cresswell (2006: 22), the divide between public and private space is a type of geographical imagination forming the basis of capitalist and patriarchal relations. Social reproduction is divided from workplace production and commonly, feminized, undervalued and relegated to the private sphere (Major and Winters 2013: 146 citing Luxton and Corman 2001; Armstrong and Laxer 2006). Analyzing these collective bargaining agreements, along with worker mobility, draws attention to how the unionized workplace distinctly overlaps with private space. In relation to union organizing and bargaining, childcare and healthcare have started to become union concerns in different sectors beginning in Canada in the 1970s (Smith 2014), foregrounding the issue of social reproduction in the private sphere and its relationship to paid employment. The changing nature of what counts as a union issue coincides not only with an increased focus on union renewal but also with more women entering unionized job markets. In this analysis employment mobility and collective bargaining agreements complicate the relationship between paid employment and social reproduction. One the one hand, collective agreements respond to mobility by extending into workers' lives including their commutes and the places they live while at work. On the other hand, the structure of long-distance commuting work pushes up against redefining concerns such as childcare as union issues, since matters affecting families and home life are geographically divided from the workplace by hundreds of kilometres in some cases. The local unions in Alberta have limited to no power to affect change in areas outside of their local jurisdiction, nor do they necessarily have incentives to tackle these issues even if they could create change.

Looking to some of the other literature on the RMWB and longdistance commuters can help provide a context for why local workers would be given preference in these collective agreements. Because longdistance commuters may have limited ties to the community and a perceived disregard for the consequences of their actions, some local residents fear more "work camp[s] for the construction workers could mean more drunken hooligans and broken windows..." (CBC News 2007: par. 
2). As Storey (2010: 1165) explains, many people express concern about the "cost of development associated with a large transient population" who make little contribution to the community but "may have high social costs as a result of increases in crime, drug use, prostitution, gambling and similar activities". Knowing this background information may help explain why employers and companies preferentially hire local residents and codified this hiring practice into collective agreements under Local Residence Preference clauses.

Related to the actual hiring protocols, the preference for local residents and the systems policing these categories not only assuage anxiety over a large transient population entering a community but also combat what is known as the "fly-over effect" - when mobile workers and companies from other locations are the main beneficiaries of resource development and extraction rather than local communities (Storey 2010: 1163). The RMWB has focused on encouraging people to set up a permanent residence in the area. For example, a Wood Buffalo municipal development document (2011: 12) suggests that "by building attractive, livable communities that offer a high quality of life, we can foster a sense of home and belonging that will attract residents to settle in the region for the long-term". Overall, the issues related to home and work communities raise questions about the divide between workers' homes and workplaces.

We can see how certain public and private spaces are divided out by considering the state-market-family nexus in the social reproduction framework. The public and private sphere have been separated by the categorization of waged work and social reproduction in the two spheres respectively. This divide has not only led to a gendering of certain kinds of work but also a gendering of the two spaces (Armstrong and Armstrong 2010). This divide between the spaces has manifested itself in different patterns of job flexibility and mobility for men and women. For the most part, men have been the ones to take on the long-distance commutes (RMWB 2013: 10). Women who do become long-distance commuters are far more likely to be employed servicing the trade workers in the camps (Ferguson 2011: 110); in other words, the female workers often are responsible for the social reproduction that takes place at the camp. This gender divide between types of work reinforces connecting women to domestic duties and men to industry or the market. These connections are reiterated in how femininity is linked to a lack of movement and masculinity is connected with movement. Janet Wolff (cited in Cresswell 2006: 54) notes how travel routines often exclude women and reiterate masculine forms of mobility. Women are drawn to flexible jobs allowing them to juggle the "second shift" in the private sphere 
they might have when they go home to their families (Hochschild 2012). The need for flexibility in this sense has pushed women into certain occupations allowing them to have somewhat more flexible hours and stay closer to home (Dorow 2015; Hill et al. 2008). We have also seen increasing flexibility with more work that is part-time, part-year, seasonal with an increase in smaller workplaces and home-work arrangements (Briskin 1994). Home-work arrangements traditionally held by women are particularly isolating and provide limited room for improvement or learning (Armstrong and Armstrong 2010). In terms of long-distance commuters in Fort McMurray, men are far more likely to take up these work arrangements, reinforcing their association with mobility, while women who do participate in long-distance commutes still maintain their connection to private feminized labour through their employment duties (Dorow 2015). This trend persists despite a number of collective agreements $(27 / 50)$ promoting female workers in their trade.

While some camp rules are included in collective bargaining agreements it is interesting that a whole other agreement is dedicated to governing the room and board, or places of social reproduction, for these workers. This separate agreement seems to suggest that although official collective agreements perhaps do not legally cover these areas, or the parties do not want the agreements to cover these areas, there is still some effort on behalf of unions and employer associations to affect these parts of workers' lives. However, this effort only extends to the private space provided by the employer and does not mention the private space of the workers' personal homes.

Although these private/public divides and arrangements are often financially necessary for families, they support a traditional structure dividing workers and union issues from private homes - reflecting Yates' (2011: 590) assertion that industrial relations arrangements assume a distinction between work/labour market and home/personal relations as well as Vosko's (2006) claims that many structures are built on the SER model of male breadwinners. The distance between the worksite and the private home of workers also means that most of the issues related to social reproduction stay in the home, out of sight for both unions and employers. Workers with children who are unable to find adequate childcare from either the state, market, or their families and friends have to deal with childcare wherever their home is, as the distance further separates the social reproduction in this private sphere from the workplace and collective bargaining agreements.

Conversely, the camp rules and regulations agreement seems to showcase how unions have influenced the employer-provided private space of workers in camps - areas where social reproduction takes place. 
This collective agreement expansion begs the question why unions have not influenced other issues facing these long-distance commuters even though an argument could be made that this work arrangement has caused issues for workers' personal lives. As workers become increasingly mobile and they bring certain aspects of social reproduction with them to the worksite location, such as room and board which is included in many collective agreements. At the same time, many other issues remain necessarily rooted in private lives, such as childcare that is absent from the agreements and seemingly beyond the reach of labour unions and employers.

\section{Conclusion}

By and large, the person who typically becomes a long-distance commuters living in temporary camp accommodations in Alberta is a middle-aged male (RMWB 2013: 10). These men bring money from Alberta to other provinces. These opportunities help improve quality of life for those who would otherwise be unable to find work and even allow people to stay in their towns when they would be otherwise forced to relocate (Ferguson 2011: 113). The long-distance commuter is an ultimately flexible resource easily dismissed and sent to another geographical location depending on the needs of capital. The reliance of capital on temporary forms of labour is a basic idea in political economy migration literature (Ferguson 2011: 113). These workers are particularly useful for industries experiencing boom-and-bust dynamics/economies such as the Athabasca oil sands. Within these mobility structures, the social reproduction work of long-distance commuters is shifted at times to whomever or whatever is available. The rules and regulations covered in this analysis set the conditions for gendered, work/private arrangements, which in turn set the boundaries of what is and is not considered a union issue and therefore what is included in collective agreements.

Yates (2011) identifies one of the pitfalls of the gender-spatial argument; it fails to account for the diverse experiences of all workers and families. Although most of the mobile workers in this case are men who are part of families with dependents not all women do care work the same way for dependents. Still, as Yates (2011: 598) reminds us, "there is an inseparableness of women's roles and social responsibilities of caring and their limited choices for work, and ways of approaching work". While Yates (2011) focused on how unions can help organize women as workers, it is equally important to examine how unions organize workers as members of communities. Essentially, the issues women bring to 
their unions - such as childcare - are critical for unions to consider when workers have families or other dependents. Indeed, unions should strive to protect workers across the variety of ways their employment affects their lives. Although the effects of employment structures governing long-distance commuters extend into their private lives, the collective agreements analyzed here have yet to extend to cover this space. In spite of the absence of clauses covering the private/home life of long-distance commuters, unions could still be doing important work in areas outside of or not yet incorporated into collective agreements.

These work and mobility arrangements construct a population of precarious workers while at the same time the extension and contraction of public and private space occurs along gendered divides (Cresswell and Uteng 2008). Thus, mobility and employment can illuminate relations of production, particularly, social reproduction. The ultimate contribution of this paper is to draw attention to the role of trade unions in these arrangements through collective bargaining agreements. Further research may see trade unions as an important mediating factor in how workers and their communities experience mobility especially during economic downturns. Future researchers may be interested in drawing connections between the mobility of capital and the mobility of workers, which may also be mediated by labour unions, or investigating if the mobile experiences of workers are different when mediated by unions or not.

\section{REFERENCES}

A Workforce Strategy for Alberta's Construction Industry. 2007. Accessed January 25,2015 . http: //work.alberta.ca/documents/workforce-strategy-construction-industry.pdf

Agreement on Internal Trade July 1 1995. Accessed January 19 2015. http: // www.ait-aci.ca.

Alberta Provincial Carpenters Collective Agreement for the General Construction Sector between Construction Labour Relations - An Alberta Association, Carpenters Trade Division and Alberta and Northwest Territories Regional Council of Carpenters and Allied Workers and United Brotherhood of Carpenters and Joiners of America, Local \# 1325, Edmonton and Local \# 2103, Calgary (2011-2015).

Armstrong, Pat and Hugh Armstrong. 2010. The Double Ghetto: Canadian Women and their Segregated Work. Don Mills: Oxford University Press.

Armstrong, Pat and Kate Laxer. 2006. Precarious work, privatization, and the health-care industry: The case of ancillary workers. In Precarious Employment: Understanding Labour Market Insecurity in Canada, edited by Leah Vosko, 114-138. Montreal: McGill-Queen's University Press. 
Bakan, Abigail and Daiva Stasiulis. 1997. Not One of the Family: Foreign Domestic Workers in Canada. Toronto: University of Toronto Press.

Barnetson, Bob and Jason Foster. 2014. The political justification of migrant workers in Alberta, Canada. Journal of International Migration and Integration. 15(2): 349-370.

Barber, Gardiner. 2008. The ideal immigrant? Gendered class subjects in Philippine-Canada migration. Third World Quarterly. 29(7): 1265-1285.

Bell, Martin and Gary Ward. 2000. Comparing temporary mobility with permanent migration. Tourism Geographies. 2: 97-107.

Bezanson, Kate and Meg Luxton. 2006. Social reproduction and feminist political economy. In Social Reproduction: Feminist Political Economy Challenges Neo-Liberalism by Kate Bezanson and Meg Luxton, 3-10. Montreal: McGill-Queen's University Press.

Borges, Marcelo J. and Susana B. Torres. 2012. Company Towns: Labor, Space, and Power Relations Across Time and Continents. New York: Palgrave Macmillan.

Briskin, Linda. 2011. Trade unions, collective agency, and the struggle for women's equality: Expanding the political empowerment measure. In S. Franzway, M. M. Fonow, \& V. M. Moghadam Eds., Making Globalization Work for Women: The Role of Social Rights and Trade Union Leadership, 213-243. Albany: State University of New York Press.

Briskin, Linda. 2006. Victimization and agency: The social construction of union women's leadership. Industrial Relations Journal. 37(4): 359-378.

Briskin, Linda. 1994. Equity and economic restructuring in the Canadian labour movement. Economic and Industrial Democracy. 15(89): 89-112.

Building Trades of Alberta. Accessed January 19, 2015. http: //bta.ca.

Camfield, David. 2011. Canadian Labour in Crisis: Reinventing the Workers' Movement. Halifax: Fernwood Publishing.

Canadian Charter of Rights and Freedoms, s 2, Part 1 of the Constitution Act, 1982, being Schedule B to the Canada Act 1982 (UK) 1982, c 11.

CBC News. 2007. Fort McMurray work camp doesn't life up to fears. Canadian Broadcast Company. Accessed January 192015 http: //www.cbc. ca/news/canada/edmonton/fort-mcmurray-work-camp-doesn-t-live-upto-fears-1.689683).

Cohen-Vogel, Lora. 2013. Seniority provisions in collective bargaining agreements and the "Teacher Quality Gap". Educational Evaluation and Policy Analysis. 35(3): 324-343.

Construction Camp Rules and Regulations (2010-2018). For Construction Camp Accommodations approved by the Building Trades of Alberta and Construction Labour Relations - An Alberta Association. 
Construction Labour Relations - An Alberta Association. Accessed January 19, 2015. https: //clra.org.

Construction Sector Council. 2005. Working Mobile: A Study of Labour Mobility in Canada's Industrial Construction Sector.

Cresswell, Tim. 2006. On the Move: Mobility in the Modern Western World. New York: Routledge.

Cresswell, Tim and Peter Merriman. 2011. Introduction: Geographies of mobility - Practices, spaces. In Geographies of Mobility: Practices, Spaces, Subjects by Tim Cresswell and Peter Merriman, Eds. 1-15. Aldershot: Ashgate.

Cresswell, Tim and Tanu Priya Uteng. Eds. 2008. Gendered Mobilities. Aldershot: Ashgate.

Denzin, Norman K. and Yvonna S. Lincoln. 1994. Handbook of Qualitative Research. Thousand Oaks: Sage Publications.

Dorow, Sara. 2015. Gendering energy extraction in Fort McMurray. In Alberta Oil and the Decline of Democracy in Canada edited by Meenal Shrivastava and Lorna Stefanick, 275-292. Athabasca University Press.

Edensor, T. 2011. Commuter: Mobility, rhythm and commuting. In Geographies of Mobilities: Practices, Spaces, Subjects Eds. Tim Cresswell and Peter Merriman, 189-204. Aldershot: Ashgate.

Ferguson, Nelson. 2011. From coal pits to tar sands: Labour migration between an Atlantic Canadian region and the Athabasca oil sands. Just Labour: A Canadian Journal of Work and Society. 17: 106-118.

Flecker, Karl. 2010. Building a disposable workforce through temporary migration policy. Canadian Issues. (Spring): 99-103.

Foster, Jason and Alison Taylor. 2013. In the shadows exploring the notion of "community" for temporary foreign workers in a boomtown. Canadian Journal of Sociology. 38(2): 167-190.

Freeman, Sunny. 2015. The 4,000 kilometre commute: How the struggle for a living wage gave rise to Canada's own temporary migrant worker. The Huffington Post. Accessed on January 19, 2015 http: //www.huffingtonpost. ca/2014/12/16/miramichi-oilsands-alberta-working-poor n 6335842 . $\underline{\mathrm{html}}$.

Frege, Carola and John Kelly. Ed. 2004. Varieties of Unionism: Strategies for Union Revitalization in a Globalizing Economy. Oxford: Oxford University Press.

Fudge, Judy. 2012. The precarious migrant status and precarious employment. The paradox of international rights for migrant workers. Comparative Labor Law and Policy Journal. 34(1): 95-132.

Fudge, Judy and Fiona MacPhail. 2009. The Temporary Foreign Worker Program in Canada: Low-skilled workers as an extreme form of flexible labour. Immigration and Nationality Law Review. 30(1): 843-886. 
Green, Anne E. 2004. Is relocation redundant? Observations on the changing nature and impacts of employment-related geographical mobility in the UK. Regional Studies. 38(6): 629-641.

Hanson, Susan. 2010. Gender and mobility: New approaches for informing sustainability. Gender, Place \& Culture: A Journal of Feminist Geography. 17(1): 5-23.

Hennebry, Jenna L. and Kerry Preibisch. 2012. A model for managed migration? Re-examining best practices in Canada's Seasonal Agricultural Worker Program. International Migration. 50(1): 19-40.

High, Steven. 2003. Industrial Sunset: The Making of North America's Rust Belt, 1969-1984. Toronto: University of Toronto Press.

Hill, E. Jeffrey, Jenet I. Jacob, Laurie L. Shannon, Robert T. Brennan, Victoria L. Blanchard and Giuseppe Martinengo. 2008. Exploring the relationship of workplace flexibility, gender, and life stage to family-work conflict, and stress and burnout. Community, Work \& Family. 11(2): 165-181.

Hochschild, Arlie Russell. 2012. The Second Shift: Working Families and the Revolution at Home. New York: Penguin Books.

Hunt, Gerald and David Rayside. 2000. Labor union response to diversity in Canada and the United States. Industrial Relations. 39(3): 401-444.

Julius, Daniel J. and Patricia J. Gumport. 2003. Graduate student unionization: Catalysts and consequences. The Review of Higher Education 26(2): 187-216.

Kiss, Simon and Vincent Mosco. 2005. Negotiating electronic surveillance in the workplace: A study of collective agreements in Canada. Canadian Journal of Communication. 30(4): 549-564.

Kumar, Pradeep and Christopher Schenk. Ed. 2006. Paths to Union Renewal: Canadian Experiences. Peterborough: Broadview Press.

Lucas, Rex. 2008. Minetown, Milltown, Railtown: Life in Canadian Communities of Single Industries. Don Mills: Oxford University Press.

Luxton, Meg and June Corman. 2001. Getting by in Hard Times: Gendered Labour at Home and on the Job. Toronto: University of Toronto Press.

Major, Claire and Tracy Winters. 2013. Community by necessity: Security, insecurity, and the flattening of class in Fort McMurray, Alberta. Canadian Journal of Sociology. 38(2): 141-165.

Mertins-Kirkwood, Hadrian. 2014. Labour Mobility in Canada: Issues and Policy Recommendations. Canadian Labour Congress.

New West Partnership Trade Agreement. 2010. Accessed January 25, 2015. http: //www.newwestpartnershiptrade.ca

Newhook, Julia Temple, Barbara Neis, Lois Jackson, Sharon R. Roseman, Paula Romanow and Chrissy Vincent. Employment-related mobility and the 
health of workers, families, and communities: The Canadian context. Labour/Le Travail. 67(Spring): 121-156.

Palmer, Bryan D. 1992. Working-class Experience: Rethinking the History of Canadian Labour, 1800-1991. Toronto: McClelland \& Stewart.

Partridge, Jamie and James Nolan. 2005. Commuting on the Canadian prairies and the urban/rural divide. Canadian Journal of Administrative Sciences. 22(1): 58-72.

Phellen, Craig. Ed. 2007. Trade Union Revitalization: Trends and Prospects in 34 Countries. New York: Peter Lang.

Preibisch, Kerry and Leigh Binford. 2007. Interrogating racialized global labour supply: An exploration of the racial/national replacement of foreign agricultural workers in Canada. The Canadian Review of Sociology and Anthropology. 44(1): 5-36.

Provincial Cement Masons Collective Agreement for the General Construction Sector in Alberta, Canada and Construction Labour Relations - An Alberta Association, Cement Masons Trade Division and Operative Plasterers' and Cement Masons' International Association of the United States and Canada Local Union 222 (2011-2015).

Provincial Insulators Collective Agreement for the General Construction Sector between Construction Labour Relations - An Alberta Association Insulators Trade Division and The International Association of Heat and Frost Insulators and Allied Workers, Local Union \#110 Edmonton and Calgary (2011-2015).

Refractory Bricklayers - Construction Collective Agreement between Construction Labour Relations, An Alberta Association Bricklayers Trade Division and Local Union \#1 Edmonton and Local Union \#2 of the International Union of Bricklayers and Allied Craftworkers (2015-2019).

(RMWB) Regional Municipality of Wood Buffalo. 2013. Municipal Census 2012. Executive Summary. 1-13.

Regional Municipality of Wood Buffalo. 2011. Municipal Development Plan: Big Spirit, Big Ideas, Big Plan. 1-170.

Rose, Joseph B. 2012. Reforming the structure of collective bargaining: Lessons from the construction industry. Canadian Labour \& Employment Law. 17(2): 403- 411.

Roseman, Sharon R., Pauline Gardiner Barber, Barbara Neis. 2015. Towards a feminist political economy framework for analyzing employment-related geographical mobility. Studies in Political Economy. 95(Spring): 175203.

Salazar, Noel B. 2011. The power of imagination in transnational mobilities. Identities: Global Studies in Culture and Power. 18(6): 576-598.

Schiller, Nina Glick and Noel B. Salazar. 2013. Regimes of mobility across the globe. Journal of Ethnic and Migration Studies. 39(2): 1-18. 
Sheller, Mimi and John Urry. 2006. The new mobilities paradigm. Environment and Planning A 38(2): 207-226.

Smith, Julia. 2014. An "Entirely Different" Kind of Union: The Service, Office, and Retail Workers' Union of Canada (SORWUC), 1972-1986. Labour/ Le Travail. 73(Spring): 23-65

Statistics Canada 2015. Annual Demographics Estimates. http: //www.statcan. gc.ca/pub/91-215-x/91-215-x2015000-eng.htm.

Storey, Keith. 2010. Fly-in/fly-out: Implications for community sustainability. Sustainability 2(5): 1161-1181.

Trade, Investment and Labour Mobility Agreement. 2006. Accessed January 25, 2015. http: //www.tilma.ca/the agreement.asp

Tucker, Eric and Brendan Jowett. 2014. Employment-related geographical mobility and collective bargaining in Canada. Report prepared for: On the Move, Policy Component July, 2014.1-58.

Vosko, Leah F. 2006. Precarious Employment: Understanding Labour Market Insecurity in Canada. Montreal: McGill-Queen's University Press.

Vosko, Leah F. and Lisa Clarke. 2009. Canada: Gendered precariousness and social reproduction. In Gender and the Contours of Precarious Employment by Leah Vosko, Martha MacDonald and Lain Campbell, 26-42. New York: Routledge.

Yates, Charlotte. 2011. Organizing women in the spaces between home, work and community. Relations Industrielles/Industrial Relations. 66 (4): 585603.

Yates, Charlotte. 2006. Women are the key to union renewal: Lessons from the Canadian labour movement. In Kumar and Schenk. Eds. Paths to Union Renewal: Canadian Experiences. 103-112. Peterborough: Broadview Press.

\section{ACKNOWLedgements}

The author would like to thank the anonymous reviewers for their feedback and suggestions, as well as the editors Stephanie Sodero and Nicolas Scott for seeing the special edition through. A special thank you to Sara Dorow for her thoughts and generosity throughout the project.

Susan Cake is a PhD Candidate in the Sociology Department at the University of Alberta. Her current SSHRC-funded research examines how nurses' unions communicate their relevance to their membership and how the union members understand this relevance.

E-mail: cake@ualberta.ca 